NBER WORKING PAPER SERIES

\title{
INSURANCE UNDERWRITER OR FINANCIAL DEVELOPMENT FUND: WHAT ROLE FOR RESERVE POOLING IN LATIN AMERICA?
}

\author{
Barry Eichengreen \\ Working Paper 12451 \\ http://www.nber.org/papers/w12451 \\ NATIONAL BUREAU OF ECONOMIC RESEARCH \\ 1050 Massachusetts Avenue \\ Cambridge, MA 02138 \\ August 2006
}

The views expressed herein are those of the author(s) and do not necessarily reflect the views of the National Bureau of Economic Research.

C 2006 by Barry Eichengreen. All rights reserved. Short sections of text, not to exceed two paragraphs, may be quoted without explicit permission provided that full credit, including $(\odot$ notice, is given to the source. 
Insurance Underwriter or Financial Development Fund: What Role for Reserve Pooling in Latin America?

Barry Eichengreen

NBER Working Paper No. 12451

August 2006

JEL No. F0, F02, F39

\begin{abstract}
The accumulation of international reserves by emerging markets raises the question of how to best utilize these funds. This paper explores two routes through which the pooling of reserves could enhance stability and welfare. First, the reserve pool could be used for emergency lending in response to sudden stops. Second, a portion of the reserve pool along with borrowed funds could be used to purchase contingent debt securities issued by governments and corporations, helping to solve the first-mover problem that limits the liquidity of markets in these instruments and hinders their acceptance by private investors. This paper argues that the second option is more likely to be feasible and productive.
\end{abstract}

Barry Eichengreen

Department of Economics

University of California

549 Evans Hall 3880

Berkeley, CA 94720-3880

and NBER

eichengr@econ.berkeley.edu 


\title{
Insurance Underwriter or Financial Development Fund: What Role for Reserve Pooling in Latin America? ${ }^{1}$
}

\author{
Barry Eichengreen \\ University of California, Berkeley \\ July 2006
}

\section{Introduction}

The unprecedented accumulation of international reserves by emerging markets raises the question of how to best utilize these funds. Should they be held as a war chest to guard against the risk of financial crisis? Or should they be used to recapitalize weak banking systems, following the example of China? Could the resource cost be limited by pooling the holdings of different central banks? If so, to what objectives should this reserve pool be put? Should it be used as an insurance fund to protect economies from the effects of capital account crises? Rather than supplying financial assistance after the fact, might it be used to build stronger national and regional financial systems and encourage the introduction of contingent claims that limit the susceptibility of emerging markets to financial crises? This paper considers these questions with reference to the case of Latin America and the Caribbean and, in particular, from the point of view of the Andean countries participating in the Latin American Reserve Fund (FLAR).

In actual fact, initiatives along these lines have been rather more visible recently in Asia than in Latin America. In 1999 the ASEAN countries agreed to create an Asian Surveillance Process (ASP) to provide semi-annual surveillance reports to be reviewed at meetings of ASEAN finance ministers every six months. The ASP can be thought of as a

\footnotetext{
${ }^{1}$ The paper was prepared for a project on strategies and actions to strengthen the role of regional financial funds, sponsored by the Latin American Reserve Fund (FLAR) and the Economic Commission for Latin America and the Caribbean (ECLAC). An earlier version was preented to a conference organized by FLAR in Lima, Peru on July 16-17, 2006. I thank Humberto Mora and his colleagues at FLAR for helpful comments and Raul Razo-Garcia for assistance.
} 
mechanism through which the participating countries commit to exchanging information and engaging in frank discussions of economic and financial conditions, developing a peer review process designed to enhance macroeconomic and financial stability in the region, identifying early warning signs of the risk of financial crisis, encouraging unilateral or collective action to avert such risks, and monitoring global economic and financial developments. This surveillance is a logical way of anticipating risks to regional financial markets and identifying circumstances justifying the activation of regional lender-of-last-resort facilities. In 2000, the ASEAN+3 countries took a modest step in the direction of creating such facilities, establishing the Chiang Mai Initiative (CMI) to provide liquidity support to countries experiencing short-run balance of payments problems. The CMI describes a set of basic principles and procedures for expanding the pre-existing ASEAN Swap Arrangement and creating a new network of bilateral swap arrangements. $^{2}$ In August 2003 ASEAN+3 finance ministers then endorsed an Asian Bond Markets Initiative (ABMI) to foster an active and liquid secondary market in localcurrency bonds and develop the infrastructure needed for the growth of local bond markets, by inter alia using official resources to create and fund an Asian Regional Guarantee Facility to provide credit guarantees. And, at roughly the same time, the Executives’ Meeting of East Asia-Pacific Central Banks (EMEAP) launched an Asian Bond Fund $(\mathrm{ABF})$ to catalyze the growth of local bond markets by allocating a portion of the reserves of regional central banks to purchases of government and quasi-government securities.

\footnotetext{
${ }^{2}$ All the details of existing bilateral swap arrangements negotiated under this umbrella are not publicly known. Estimates of the magnitude of the swaps available to the 13 participating countries are on the order of $\$ 35$ billion. The first ten per cent can be drawn automatically, while the remainder is subject to conditions.
} 
Latin America has not seen equally ambitious initiatives, although the region does have a considerable history of monetary and financial cooperation. The Economic Commission for Latin America and the Caribbean (CEPAL) provides surveillance of regional macroeconomic and financial developments. The Secretariat of the Andean Community (CAN) has coordinated initiatives on macroeconomic harmonization, mainly on the basis of inflation and fiscal targets. Recently those initiatives have been coordinated with other blocks like MERCOSUR and the Central American Common Market, notably through the REDIMA initiative sponsored by the European Union and organized by CEPAL. FLAR provides external financing to central banks to support the balance of payments, provide emergency liquidity assistance, and facilitate restructuring of public debt. ${ }^{3}$ In addition it has promoted, in coordination with CEPAL and CAN, the development of a forum of officials from its member countries to discuss macroeconomic and financial issues affecting the region on the basis of technical rather than political analysis. But these initiatives have not been as ambitious and visible as their Asian counterparts.

Why not is an interesting question. For one thing, Latin American countries have not accumulated quite the same extraordinary quantities of reserves as their Asian counterparts. (See Figure 1.) For better or worse they have not relied on exports for demand as heavily as the principal Asian countries, rendering them quicker to move away from undervalued exchange rates based on dollar pegs. With their exchange rates floating (subject to some intervention), they have not accumulated such massive reserves as a result of sterilization operations designed to keep their currencies down. Now, with a

\footnotetext{
${ }^{3}$ Since 1978 for the five Andean countries (Bolivia, Colombia, Ecuador, Perú and Venezuela) and subsequent for Costa Rica.
} 
growing number of Latin American countries running current account surpluses and governments and central banks concerned to avoid excessive appreciation, reserve accumulation may accelerate. So too then may discussions of how to deploy these resources to productive ends.

The remainder of this paper assesses options for regional reserve pooling. It starts by reviewing the accumulation of reserves by the countries of Latin America and the Caribbean. It then analyzes two goals to which these resources might be directed: the provision of country insurance and the creation of stronger financial systems and contingent financial claims that would limit the region's exposure to financial instability. In both cases, answers to the question of whether regional reserve pooling would be effective are complex. My own view is that an effort to use these resources to promote the development of financial markets and instruments conducive to effective risk sharing is more likely to be productive than an attempt to provide coinsurance at the regional level.

An important issue is the relationship between these regional initiatives and the global financial institutions: the International Monetary Fund and World Bank. Arguably, the Fund and the Bank already seek to advance the same objectives that might figure in the objective function of the operators of a regional reserve pool. This compels one to ask why a regional initiative might be able to do so more effectively and how the activities of a regional fund should be coordinated with those of the global financial institutions. In fact, this same issue has arisen in Asia, on whose experience I draw in the penultimate section. 


\section{What has Happened to Reserves?}

The motivation for this analysis is the very considerable accumulation of reserves by Latin American countries. This section provides three perspectives on this development. A first perspective is Figure 1 above, which shows the growth of reserves in dollar terms. A second rather different perspective is Figure 2, which shows reserve cover as a percentage of imports, short-term debt, and broad money. A striking fact is that Latin America's reserves have not risen significantly relative to imports. Although reserves have risen, in other words, the region's commercial transactions have grown right along with them. ${ }^{4}$ In contrast, Latin reserves have risen relative to short-term external debt and the broadly-defined money supply. Reserves relative to short-term debt can be thought as reflecting the authorities' concern with rollover risk, while reserves relative to broad money is commonly taken as an indicator of reserve adequacy in the event of a financial crisis, since it reflects the potential for resident-based capital flight from the currency. ${ }^{5}$ These patterns thus suggest that recent reserve accumulation is indicative of a demand for insurance against financial shocks.

A third, complementary perspective is provided by the empirical literature on the demand for reserves. Aizenman and Lee (2005) contrast two explanations for reserve accumulation in the last ten years: "mercantilist motives" (the desire on the part of export-dependent economies to keep their exchange rates low and exports competitive in the interest of growth) and "precautionary motives" (the impulse to accumulate additional reserves as protection against the risk of financial crises). They estimate the relative

\footnotetext{
${ }^{4}$ One possible implication is that the governments and central banks in Latin America and the Caribbean do not yet possess the abundance of reserves necessary in order to be able to devote some fraction of them to a still unproven reserve-pooling arrangement. But yet another possible implication is that the still-limited extent of reserves makes it all the more imperative that the region develop more efficient ways of deploying its holdings.

${ }^{5}$ See IMF (2003).
} 
importance of these two influences using data for a panel of 53 advanced and developing countries. In addition to the standard determinants of the demand for reserves (population, per capita income, imports as a share of GDP, and exchange rate volatility calculated from the monthly exchange rate against the U.S. dollar), they include proxies for mercantilist motives (a three-year moving average of the rate of growth of real exports and a measure of real undervaluation) and precautionary motives (dummy variables for the Mexican crisis and Asian crisis, interacted with a dummy variable for emerging markets or alternatively with a dummy variable for either just Asia or Latin America). Their basic finding is that both motives are significant statistically but that precautionary factors have been more important economically. The Mexican and Asian crises both ratcheted up emerging markets' demand for international reserves. While Asian demands responded only to the Asian crisis, Latin American demands ratcheted up following both the Mexican crisis and its Asian successor.

A limitation is the special nature of the Aizenman-Lee sample, which includes only seven LAC countries: Argentina, Brazil, Chile, Colombia, Mexico, Peru and Venezuela. In addition, nearly half of their sample is made up of advanced economies whose behavior is different because the extent of their foreign-currency denominated debt (which is minimal) and hence their vulnerability to crises (which is correspondingly less). I therefore replicated Aizenman and Lee's analysis on an expanded sample of more than 150 countries, including all of the principal Latin American and Caribbean economies. The results carry over: both mercantilist and precautionary motives matter, but the precautionary motive continues to explain more of the variation in countries' accumulation of reserves. In LAC, there has been a noticeable increase in the demand for 
reserves, holding constant income growth, openness and exchange rate variability, in response to the Mexican and Asian financial crises. ${ }^{6}$

The logical conclusion to draw from these results is that Latin American and Asian countries have been concerned to accumulate international reserves since the mid1990s not just due to the growth of their international transactions but also in response to the perceived rise in risk associated with financial globalization. This in turn points to the question of whether a cooperative strategy that involves reserve pooling might be the best means to these ends.

\section{The Case for Country Insurance and Critiques}

One way of more effectively mobilizing reserves would be by pooling them through an organization like FLAR and using them for coinsurance. One could think of insurance against terms-of-trade shocks, capital-account shocks, global-growth shocks, and local-growth shocks. The question of what to insure against should be based on two criteria. First, if the shock occurs, it should have consequences severe enough to justify the fixed costs of arranging the insurance. People don't take out insurance to protect themselves against the dry-cleaning costs of spilling soup on their tie; rather, they rely on straightforward preventive measures like tucking a napkin under their collar and, if a stain nonetheless occurs, they pay the cleaning costs out of cash on hand. Second, the moral hazard associated with the insurance should be limited. Otherwise the provision of insurance may be actuarily infeasible or welfare reducing.

\footnotetext{
${ }^{6}$ It is worth noting that Aizenman and Lee's 1997-8 Asian-crisis dummy would of course be highly correlated with a 1998-9 Brazilian crisis dummy, which could also help to explain LAC's apparent sensitivity to this variable.
} 
As alluded to in Section 2, the context for such proposals is the problem of sudden stops and reversals in the direction of capital flows. ${ }^{7}$ Sudden stops can destabilize financial systems and plunge economies into recession. Recent studies suggest that the output costs can exceed 5 per cent of GDP in the year following the onset of the event. ${ }^{8}$ Thus, there is a rationale for insuring against sudden stops by holding international reserves. $^{9}$

Sudden stops also cluster in time. (See Figure $3 .{ }^{10}$ ) An interpretation of this (see e.g. Calvo, Izquierdo, and Mejia 2004) is that they have to do with the behavior of global financial markets as well as country policies. Some take this to mean that their incidence would be unlikely to increase as a result of the provision of country insurance. Calvo (2005) takes the fact that growth recovers quickly from sudden stops as further evidence that country policies are not at the root of this phenomenon. ${ }^{11}$ He concludes that sudden stops and the frequency of financial crises in emerging markets reflect inefficiencies in

\footnotetext{
${ }^{7}$ See Calvo (1998) and Calvo and Reinhart (1999). Operationalizing the concept of sudden stops is not straightforward, as we shall see, which itself poses problems for the concept and operation of an insurance mechanism. Caballero and Panageas (2005) define this event as an instance where external funding declines by at least 10 per cent.

${ }^{8}$ Calvo et al. (2004) select episodes characterized by large output losses. Other authors analyzing a larger sample of sudden stops not selected on this basis generally find smaller output effects, on the order of 1-2 per cent of GDP. See e.g. Edwards (2005).

${ }^{9}$ This observation can be seen as an outgrowth of the original buffer-stock model of international reserves (Heller 1970), in which countries hold reserves as a buffer against balance-of-payments shocks (although in the original model, developed for an era of closed capital accounts), it was shocks to the current account (as captured by, inter alia, export variability) that motivated the reserve-holding decision.

${ }^{10}$ Figure 3 is based on the measure of sudden stops in Eichengreen, Gupta and Mody (2005). The blue bar is for Latin American and Caribbean countries, the red bar for all emerging markets including LAC. Of course, a number of commentators suggest that these data from the past may be an imperfect guide to the future insofar as improvements in the information and policy environments have reduced the cross-country correlation of such events. See for example Byun and Oswald (2005). One would also draw rather different implications for the covariance of shocks depending on the exact nature of the shock against which the regional reserve pool was designed to insure. For example, even if sudden stops affect a variety of different Latin American countries simultaneously, terms-of-trade shocks may have a lesser tendency to coincide: a shock to oil prices will be a positive shock to oil exporters but a negative shock to oil importers, working to reduce covariance. Thus, how seriously one takes this objection depends in addition on the precise nature of the shocks being insured against. I return to this below.

${ }^{11}$ The v-shaped nature of the output response seems to be quite general, as I have found in my own empirical work on the subject (Adalet and Eichengreen 2005).
} 
international financial markets. ${ }^{12}$ He therefore argues for the creation of a global fund offering emergency financial assistance to countries suffering from sudden stops. ${ }^{13}$ In the absence of a global fund, the insurance in question could be provided by a regional pool of reserves administered by, inter alia, FLAR.

This proposal is allied to the classic lender-of-last-resort (LLR) argument that, in response to a shock to confidence that undermines the liquidity of financial markets, the central bank should discount financial claims at a penalty rate (in order to discourage discounting by entities not in fundamental need of assistance). The difference here is that many of the external liabilities of Latin American countries are denominated in foreign currencies. Hence the ability of a national central bank to provide LLR services will be limited by its international reserves, a constraint that can be relaxed by reserve pooling.

Even if the substantial negative effects of sudden stops justify investing in insurance, holding substantial reserves continuously as protection from an infrequent event may still be costly and inefficient. ${ }^{14}$ Reserves bear a lower rate of interest than less liquid investments. While it is precisely this liquidity that makes them attractive as a form of insurance, the associated liquidity premium makes them costly. If the event in question is not just infrequent but also affects different countries at different times, then the costs of self-protection can be reduced by pooling reserves. Intuitively, sudden stops are an unusual state. Self-insuring by holding non-state-contingent financial claims on

\footnotetext{
${ }^{12}$ Such as, for example, the herding behavior that can arise in an environment of asymmetric information, in conjunction with the weakened incentive to incur the costs of acquiring complete information about borrowing countries when investors hold diversified portfolios.

${ }^{13}$ Calvo's preferred variant of the mechanism would have the stabilization fund purchase the bonds of adversely-affected economies to prevent their spreads from rising (Calvo 2002).

${ }^{14}$ See Caballero and Panageas (2005). It is like those whose houses sit atop earthquake faults (such as the present author) warehousing all the building materials and appliances needed to reconstruct his house in the event an earthquake strikes rather than simply purchasing an insurance policy from a company better positioned to pool these risks. Lee (2004) parameterizes a simple model of self-insurance and shows that full coverage (sufficient to fully offset the effects of the sudden stop) is suboptimal. I turn to alternative, potentially more efficient insurance mechanisms, in Section 4 below.
} 
the rest of the world will therefore tend to be inefficient, rendering a reserve pool on which countries draw only in certain states of the world efficiency enhancing.

A number of questions can be raised about this argument. One is why countries cannot contract for insurance commercially by establishing credit lines on international capital markets or issuing securities with embedded options that have the same insurance properties. If the argument for insurance is strong, then the private sector should be prepared to provide it for a fee. This objection seems especially compelling in light of the explosive growth of international financial markets and transactions. There has in fact been some experimentation with this practice, by inter alia Argentina in the 1990s. ${ }^{15}$ But the Argentine credit line was small, and execution was delayed until well into the crisis.

More generally, the question is why the practice is not more widespread. One possible answer is that capital requirements and other regulations prevent potential suppliers from providing insurance on the requisite scale. Commercial counterparties may also be worried about concentrated country exposures and demand a prohibitively price for the provision of contingent credit lines. Still, if the case for private insurance is strong, then financial markets and institutions adept at diversifying and repackaging risks would presumably find a way around these obstacles.

Another possibility is adverse selection. If asymmetric information prevents commercial insurers from discriminating among potential borrowers in different risk categories, then only unusually risky countries will wish to contract for such lines. The higher the fees and interest rates charged, the greater the riskiness of willing purchasers,

\footnotetext{
${ }^{15}$ The experiment in question involved a contingent repurchase contract between the Argentine central bank and a consortium of foreign banks, under which the central bank was allowed to withdraw funds in the event of a crisis via a three-month renewable credit line collateralized by dollar-denominated government bonds.
} 
causing the private market to collapse. The limitation of this argument is that potential insurers are far from ignorant of variations in country risk. Information is asymmetric, in other words, but not all that asymmetric, enabling lenders to charge different rates to borrowers subject to different levels of country risk.

A related argument is that a public insurance agency may have greater ability or stronger incentives to gather information on the financial condition of its clients, in turn enabling it to better tailor incentive-compatible contracts. An objection here is that private financial institutions with their own financial returns and performance at stake have at least as strong an incentive to invest in these monitoring functions. Yet another possibility is that commercial insurance providers have an incentive to take a short position against the country when the probability rises that it will wish to draw down its credit line. In turn this will destroy the effectiveness of the insurance (Broda and Levy-Yeyati 2003). Presumably this problem does not carry over to public insurance providers. Of course, this problem would be ameliorated if the insurance liability was securitized and widely distributed, since diversification would then provide the insurers with the protection they need (obviating the need to hedge on a large scale). But in turn this begs the question of why emerging markets find it hard to place innovative securities containing put and call options that kick in when economic conditions deteriorate, even calling for reverse payments. I return to this below.

\section{Coincident and Uncorrelated Shocks}

A second question is whether bunching -- that multiple countries experience sudden stops simultaneously - undermines the rationale for reserve pooling. If most or 
all contributing countries need to draw on the fund simultaneously because they experience shocks simultaneously, then the advantages of reserve pooling disappear. This will be true whether the simultaneity of shocks reflects global factors affecting all countries similarly or whether it reflects contagion spreading from one victim to another. The fact, documented by Glick and Rose (1998), that financial contagion has a pronounced regional element suggests that a regional reserve fund may be less effective than global insurance extended through, inter alia, the International Monetary Fund, since different regions are impacted differently and the IMF spans the entire globe. This does not destroy the argument for reserve pooling insofar as different countries may experience the shock with different degrees of severity (allowing some of the reserves of countries experiencing moderate effects to be lent to countries suffering severe effects), but it weakens it. ${ }^{16}$

The importance of this is an empirical question. A variety of approaches can be taken to identifying shocks to the balance of payments, from naïve time series analysis to structural vector autoregression to the simulation of multi-country macroeconomic models. Here I take the relatively simple approach pioneered by Dodsworth (1992) and Williams et al. (2001).

The first step is to compute the mean, standard deviation and coefficient of variation of the international reserves of each of the six members of FLAR. Results for the period 1978-2005 are shown in Table 1 (with means are expressed in millions of U.S.

\footnotetext{
${ }^{16} \mathrm{And} /$ or insofar as a regional reserve fund may be in a relatively strong position to borrow additional resources on the markets.
} 
dollars.) The coverage ratio $\mathrm{C}$ can then be expressed as follows under alternative assumptions of reserve pooling (ranging from zero pooling to full reserve pooling). ${ }^{17}$

$C_{i}=\frac{R_{i}+\sum_{j \neq I} \rho R_{i}}{\operatorname{Var}\left(R_{i}+\sum_{j \neq I} \rho R_{j}\right)}$

$R_{i}$ is the total reserves of country $i$, and $p$ is the degree of pooling, $O<p<1$. With $0<p<1$, country $i$ 's total access to reserves equals its own reserves plus the partially pooled reserves of the other countries. Coverage ratios for the six members of FLAR are shown in Table 2. Evidently, some countries like Venezuela and Ecuador are better off without pooling, while Bolivia, Costa Rica and Peru are all better off when reserves are pooled. Colombia, in contrast, is unaffected. These results flow directly from differences in the coefficients of variation in Table 1. Countries for which the level of reserves is high relative to their volatility (Venezuela, Ecuador) do not benefit from pooling with countries with fewer and more volatile reserves. For countries where reserves are relatively volatile and/or relatively smaller, the opposite will tend to be true. The imperfect correlation of national reserve fluctuations does not appear to have been pronounced enough to modify these direct effects. ${ }^{18}$

Following Williams et al., one can then compute the level of reserves that each country would have to hold in an independent state in order to enjoy the level of coverage afforded by pooling. From equation (1), we can obtain the hypothetical level of reserves HR that a country must hold in order to achieve a coverage ratio $C_{i}{ }^{*}$, given its own historical reserve variability $R_{i}$.

\footnotetext{
17 The coverage ratio is of course simply the reciprocal of the coefficient of variation in the special case where $p=0$.

${ }^{18}$ In practice, the covariance of reserve fluctuations tends to be positive, not negative.
} 
$H R=(C i *)(\operatorname{Var} R i)$

These figures are shown in Table 3. The results follow directly from Tables 1 and 2. We see that Colombia's reserves are basically unchanged. Bolivia and Peru would have to increase their reserves by more than half in order to obtain the same benefits delivered by pooling, but on a stand-alone basis. Costa Rica would have to increase its by a quarter. For Venezuela and Ecuador, the reduction in coverage under pooling translates into a decline in effective reserves.

These exercises suggest that there may be a problem of incentive compatibility in getting low-variability and high-variability countries within FLAR to pool a greater fraction of their reserves. The imperfect correlation of reserve fluctuations across countries is not pronounced enough for countries whose reserves are large relative to own-reserve volatility to benefit from pooling with neighbors whose reserves are lower and/or whose volatility is higher. (See Table 4.)

There are a number of reasons to hesitate before drawing over-strong conclusions from these results. Historical relationships may not hold in the future. The Lucas Critique suggests that reserve volatility and covariances could change as a result of the pooling arrangement. The fact that reserves in all the countries concerned have been trended upward in recent years, together with economic growth and opening, will tend to exaggerate their correlation. ${ }^{19}$ But the results here are at least a start.

\footnotetext{
${ }^{19}$ A start on attacking this problem is to regress each country's reserves on a time trend and then to set the mean of detrended reserves to the mean of actual reserves. Table 5 shows the resulting correlations; now the much lower correlation of detrended reserves suggests more scope for pooling. Table 6 confirms that the resulting standard deviations and coefficients of variation are smaller, while Table 7 confirms that more countries can gain from pooling if the detrended correlations are an accurate guide to the future. The
} 


\section{Moral Hazard}

A third question is whether sudden stops are really not a function of country policies. Empirical analyses of their incidence from Calvo, Izquierdo, and Mejia (2004) to Edwards (2005) identify roles for both internal and external factors. To quote Calvo (2005), "econometric studies do not reject the hypothesis that Sudden Stops are largely prompted by external factors but, at the same time, strongly suggest that the probability of Sudden Stops reflects domestic characteristics." In other words, even analysts emphasizing the importance of global factors acknowledge that domestic characteristics shape the impact and response to external shocks. Insofar as the relevant characteristics include policies under the control of the domestic authorities, this means that moral hazard may arise. ${ }^{20}$

Moral hazard does not render insurance infeasible, but it requires that a reasonable insurance scheme be designed to limit its extent. The obvious way of doing so is through surveillance and conditionality. Automobile insurers monitor the citations of their policy holders: drivers with too many speeding tickets find their premia raised and policies cancelled. Surveillance and ex ante conditionality can similarly limit the tendency for

calculations in Table 7 now suggest that only Costa Rica and Colombia now lose from full pooling. Whether one prefers the calculations in Table 3 or Table 7 as a guide to the prospective effects of reserve pooling hinges entirely, of course, on whether one thinks that the raw or detrended data provide a better guide to the future correlation of reserve movements.

${ }^{20}$ The extent and economic importance of moral hazard in this context is disputed; for a review of the evidence see Lane and Philips (2000). There is also the possibility that, in the presence of other distortions, adding insurance will lead to less risk taking rather than more. Thus, Cordella and Levy Yeyati (2004) show in a model of finite-lived governments where the probability of government survival declines with a rising incidence of financial crises, that insurance that reduces the risk of financial collapse may in fact encourage the authorities to invest more in policy reform (in the present context, to reduce the riskiness of their policies). Of course, there are actually two effects of insurance here: insurance that reduces the likelihood of a crisis reduces the pressure on the government to head it off, but that insurance also strengthens the incentive to pursue reforms that reduce the riskiness of the environment in the future. Predictably, the net effect is ambiguous. Cordell and Levy Yeyati show that insurance is more likely to encourage reforms that pay off in good times (since it reduces the risk of falling into a crisis in the first place) than reforms that reduce the risk of a crisis in the event that one occurs. 
macroeconomic policy makers and debt managers rendered overconfident by the existence of an insurance policy from driving the economy recklessly. Alternatively, automotive insurers may require the policy holder to take certain actions after an accident as a condition for receiving assistance: the insured may be required to provide a police report, permit his car to be inspected by an adjustor, and agree to be examined by a physician and to accept his recommended course of treatment. In the same way, central banks acting as lenders of last resort may require certain conditions to be met by financial institutions (for example, they may require full access to the books or removal of management). Emergency financial assistance by the IMF similarly comes with conditions attached.

A key question is whether such conditions are better applied ex post or ex ante. Should the operator of the reserve pool, say FLAR, announce before the fact what countries are eligible for a credit line in the event that they experience a sudden stop and specify the amount of assistance that they can expect to receive? Or should it proceed on a case-by-case basis and decide whether or not to provide additional credit once the sudden stop and the severity of the output decline have been observed?

Those who argue for insurance against sudden stops generally favor ex-ante contracts. First, the problems of illiquidity that arise when capital flows are interrupted can spiral into insolvency unless funds are disbursed quickly. Extended deliberations are not feasible in this context; rather, determining eligibility with the requisite speed requires that countries be deemed eligible for assistance ex ante. Second, if the terms and amounts of external assistance are specified ex ante, the government has a stronger incentive to take steps to expedite the economy's recovery from the sudden stop. 
Cohen and Portes (2004) describe an insurance contract in which countries prequalify for assistance if their debt ratios remain below some critical ceiling consistent with moderate spreads, say 400 basis points above LIBOR. By assumption, any crisis that the country then experiences is a crisis of liquidity, not a crisis of debt sustainability. Payments are triggered when spreads on the debt rise above the threshold level. The IMF or regional reserve fund would then lend to the country at the threshold spread. It would thus contain the effects of the sudden stop that caused spreads to rise and prevent the liquidity crisis from degenerating into a solvency crisis. Calvo (2002) offers a variant of the same class of proposals, in which his "Emerging Market Fund" would purchase the bonds of fundamentally solvent countries adversely affected by a crisis elsewhere in the world. Cordella and Levy Yeyati (2005) propose a country insurance facility that would provide eligible countries with automatic access to a credit line at a predetermined interest rate, where eligibility criteria would again focus on debt sustainability - not just the level of the debt but also its maturity and currency composition. Dervis and Ozer (2005) similarly propose a Stability and Growth Facility that would provide insurance against unforeseen shocks and for which countries would prequalify on the basis of their policies.

Chami, Sharma and Shim (2004) lay out the analytics of this approach. They assume that the insurer has two objectives: safeguarding its assets and providing for the borrowing country's welfare, which it can enhance by extending a loan. A governmental counterparty decides in each of two periods how much unobserved effort to exert in order to avoid and then recover from a financial crisis, which in turn affects how much will be asked to repay to the insurance pool. 
In this model it is preferable for the insurer to specify eligibility for assistance and the terms of the credit line - how much assistance the insured will receive as a function of the severity of the decline in output that occurs in the first period - before the fact rather than deciding ex post whether or not to extend a loan after the country enters the crisis but before the full output consequences, which only develop in the second period, are known. There is moral hazard under either contract; knowing that it stands to receive official support, the efforts of the national authorities to avert the crisis are correspondingly less. But the extent of the moral hazard affecting the authorities' efforts to recover from the crisis varies with the form of the contract. Under the ex-post contract, the crisis country repays more if it makes a greater effort to recover, which works to depress adjustment effort. In contrast, under the ex-ante contract, when terms are agreed prior the government's decision of how much adjustment effort to extend, repayment is independent of effort; hence adjustment will be greater, and outcomes will be superior from all points of view. In general, an insurer that both has a fiduciary responsibility to safeguard its assets and cares about the welfare of the crisis country will prefer an ex ante contract in which the operator of the reserve pool specifies who is eligible and the terms and amounts of the assistance that will be forthcoming.

But there is a problem of time consistency with the ex ante contract. The insurer may want to renege on its fixed commitment if it observes that the recession is severe; since it values the welfare of the insured, it may wish to offer more generous terms. Hence ex ante contracts in which the amount and terms of the credit line are fixed will 
not be credible. ${ }^{21}$ And since the insured knows this, moral hazard leading to less adjustment effort will still be a problem, surveillance and conditionality or not. ${ }^{22}$

This suggests that an organization like FLAR operating a coinsurance mechanism may wish to deem certain countries eligible for a fixed credit line, since this is better than a discretionary, case-by-case approach at preserving its own financial solvency while at the same time supporting the welfare of its members, but that the time consistency problem may undermine the feasibility of this approach and aggravate moral hazard. And if moral hazard is serious, a coinsurance arrangement may turn out to be welfare reducing rather than welfare improving for the group as a whole.

At least three further questions can be raised about these ideas. First, is a regional entity like FLAR well positioned to carry out surveillance and apply conditionality? Peer monitoring is costly and subject to increasing returns; if scale economies are strong, there may be an argument for centralizing it at a global institution like the IMF. In addition, monitoring and enforcement may also be more effective when they are delegated to a global entity like the IMF that is better insulated from political pressures emanating from a single region. It is well known that arrangements based on peer monitoring (a FLARbased coinsurance mechanism would be one involving regional peers) tend to be lax in enforcement and thus to fall down at the monitoring stage, problems that can be solved, at least in principle, by delegating these tasks to an outside entity. ${ }^{23}$

\footnotetext{
${ }^{21}$ Note that Cohen and Portes, in the article referenced above, do not address the time consistency problem. ${ }^{22}$ Theoretically, it is possible that this problem could be solved through repeated interaction between the insurer and the country, through which the former develops a reputation for acting consistently. I return to this below.

${ }^{23}$ Thus, DeMarzo, Fishman and Hagerty (2001) show that self-regulating organizations prefer fewer investigations for cheating and lower penalties in the event of detection than organizations in which these functions are delegated to an outside body. It is sometimes argued that the time consistency problem that obstructs efforts to enforce ex-ante insurance contracts can be solved by repeated interaction between the insurer and the insured, as a result of which the insurer develops a reputation for behaving consistently.
} 
Second, doesn't the unsatisfactory experience of the IMF's contingent credit line (CCL), for which no country applied prior to its elimination in 2003, raise questions about the enthusiasm of LAC countries for ex ante coinsurance? Insofar as the funders of any regional facility would value its solvency and those operating it would have an obligation to safeguard its assets, countries running risky policies that would prevent them from paying back those credits would have to be denied the privilege of borrowing. Countries might then be reluctant to apply insofar as this sent a negative signal about their financial condition. Together with the fact that the outcome was uncertain, since the application then had to be approved by the IMF's Executive Board, this seems to have been what deterred governments from applying for a CCL. ${ }^{24} \mathrm{~A}$ further problem was that eligibility could be rescinded at some future date, sending a negative signal that might precipitate a crisis.

FLAR could carry out its fiduciary responsibility by announcing unilaterally which member countries were eligible for financial assistance. But it would then send a negative signal about the financial condition of the other countries when it declared them ineligible for assistance. In turn this might render countries reluctant to participate in the coinsurance arrangement in the first place. And the exit problem would remain. ${ }^{25}$

\footnotetext{
The tendency toward forbearance evident in self-regulating organizations suggests that this bootstrap equilibrium may be hard to sustain.

${ }^{24}$ Since 1999 FLAR has also had a Contingent Credit Line (under Article $7 \mathrm{~d}$ of its by-laws). As I understand it, it has finessed the problems of potential slow disbursement and prequalification by delegating the decision of whether to extend this credit to the Executive President of the reserve fund, who can presumably act without delay in response to a capital account crisis. However, the president's fiduciary responsibility would still create the possibility that he would feel obligated to deny a request for a credit line from a member country and that this decision would then exacerbate its crisis. (Alternatively, if requests for credits were granted indiscriminately, the financial condition of the reserve pool might be threatened.) This danger may explain why only one country, Columbia, has applied for credit through this facility.

${ }^{25}$ Cordella and Levy Yeyati (2005) suggest "smoothing" the eligibility criteria so that exogenous shocks temporarily pushing a country about the eligibility threshold do not precipitate a sudden jump in interest rates and/or a crisis. While this might help for small exogenous shocks that the authorities wish to offset, it will not help for large exogenous shocks that cannot be offset in the medium term.
} 
Finally, such schemes tend to assume the ability of the agency operating the facility to discriminate between solvent and insolvent countries, where the solvent countries are still susceptible to liquidity crises and should thus be made automatic beneficiaries of the new facility. Cohen and Portes (2004) assume the existence of a well-defined amount of debt that forms the ceiling on sustainable levels. Cordella and Levy Yeyati (2005) argue that a ceiling should be defined for the overall debt-GDP ratio but also recommend that foreign-currency debt and short-term debt should receive heavier weights in the calculation of this total. They suggest imposing a ceiling on the fiscal deficit in each of the preceding three years. Calvo (2002) similarly suggests that his Emerging Market Fund would be able to efficiently discriminate between insolvent and illiquid crisis countries.

Unfortunately, in the real world there is no well defined cutoff between sustainable and unsustainable debts. Sustainability depends on forecasts of future growth rates and interest rates that are disputable and uncertain. It depends on estimates of the political will of a government and society to mobilize and transfer real resources for purposes of debt service. It thus seems unavoidable that any coinsurance facility will occasionally lend to countries that turn out to be insolvent and find it impossible to repay. Or it will not lend to countries whose problems are liquidity related, leading to complaints and recrimination. Any automatic scheme that depends on the existence of an operational distinction between insolvent and illiquid crisis countries is unlikely to be feasible in practice. ${ }^{26}$

\footnotetext{
${ }^{26}$ This argument is developed and defended at greater length in Eichengreen (2002).
} 


\section{FLAR as a Financial Development Fund}

The idea that Latin American reserves might be pooled through a regional entity like FLAR and used for coinsurance against sudden stops has some appeal. To the extent that sudden stops are imperfectly correlated across countries, pooling can be used to reduce the real resource cost of reserve accumulation. To the extent that countries suffering purely from problems of illiquidity can be identified, the substantial costs of the financial instability induced by interruptions to private capital flows can be avoided.

At the same time, there are significant obstacles to the successful implementation of such a scheme. Identifying countries whose financial problems are exclusively related to liquidity may be straightforward in theory, but doing so is difficult in practice. Insofar as such a fund also lends to countries with fundamental problems of debt sustainability, either reserves will be squandered if loans are not repaid or the financial burdens of the country will be heightened if they are. The moral hazard associated with this insurance would weaken crisis prevention and recovery effort unless it is married with effective surveillance and conditionality. And self-regulating entities, including insurance cooperatives, are prone to greater forbearance than entities whose regulation is delegated to third parties, which raises questions about the effectiveness of regional monitoring and conditionality.

The alternative is to pool some fraction of the region's reserves and use them to promote the development of financial markets and instruments that enhance resiliency to capital-flow volatility. The motivation here is two-fold: that the absence of deep and liquid markets in instruments whose returns are negatively correlated with domestic economic conditions heightens financial fragility, and that outside intervention is needed to get those markets up and running. 
The idea that the absence of suitable instruments renders emerging markets vulnerable to capital-flow volatility has been developed in the literatures on balance-sheet effects, de-facto dollarization, and original sin. The literature on balance-sheet effects emphasizes that sudden stops precipitating depreciation of the currency have strongly negative effects in emerging markets. Negative effects arise because emerging markets are net foreign debtors and because their external liabilities are disproportionately denominated in foreign currency. ${ }^{27}$ When the United States sees its currency depreciate, the main effect is to crowd in exports and stabilize output, rather than causing financial stringency. ${ }^{28}$ In emerging markets with foreign-currency-denominated liabilities, in contrast, the main effect is to raise the costs of debt service and heighten financial distress.

The literature on de facto dollarization adds the tendency for just just foreign creditors but also residents to denominate assets and liabilities in foreign currency. Net debtors will thus experience difficulties when the currency depreciates, giving rise to financial distress that can ramify. A series of studies has now documented the connection between de facto dollarization and financial fragility. Calvo et al. (2004) show that more dollarized countries have a higher incidence of sudden stops. Levy Yeyati (2004a) shows that banking crises following currency depreciation are more frequent in countries with more dollarized banking systems. Domac and Martinez Peria (2000) find that the incidence of systematic banking crises rises with the foreign-currency-liabilities-to-assets ratio of local banks. Berganza and Garcia Herrero (2004) show that sovereign spreads rise more sharply following currency depreciation in more dollarized economies.

\footnotetext{
${ }^{27}$ For the literature on balance-sheet effects, see Cespedes, Chang and Velasco (2000).

${ }^{28}$ This point is documented by Gagnon (2005).
} 
Finally, the literature on original sin emphasizes the obstacles facing emerging economies, small ones in particular, seeking to issue domestic-currency-denominated state-contingent securities whose returns co-vary negatively, or at least do not co-vary positively, with domestic economic conditions. ${ }^{29}$ It is not as if policy makers and financial market participants are ignorant of the potential for destabilizing balance-sheet effects, in other words. But emerging markets, small ones in particular, find it either difficult (Williamson 2005) or impossible (Eichengreen and Hausmann 2005a) to issue significant quantities of instruments with more desirable cyclical properties. This problem presumably reflects more than just inadequate anti-inflationary credibility: many emerging markets have the same difficulty in issuing CPI-indexed domestic-currency bonds which would insulate the country from the deterioration in the terms of trade that accompanies sudden stops while at the same time protecting investors from the inflation $\operatorname{tax}^{30}$

That this problem is particularly difficult to overcome in small countries is not a coincidence: the demand and supply sides of the market must achieve a minimum efficient scale in order for a significant volume of transactions to be sustained, something that is especially difficult in small countries. Small numbers of investors and transactions make it hard for to buy and sell without moving prices. Bid-ask spreads tend to be prohibitive in thin markets.

Thus, even if such countries have the capacity to issue innovative instruments with more desirable cyclical properties, potential issuers and investors both may be

\footnotetext{
${ }^{29}$ See Eichengreen and Hausmann (2005a) for a compendium of research adopting this perspective.

${ }^{30}$ The importance of such credibility problems can be questioned, now that inflation rates in virtually all FLAR countries (with the exception of Venezuela) have converged to levels below 5 per cent. Of course, the issue is not so much current inflation as the distribution of expectations of future inflation.
} 
deterred by the very high up-front costs that must be incurred to jump-start the market. ${ }^{31}$ In this situation, outside intervention through which a sufficient installed base of the relevant assets is created has generally been needed to initiate activity. The market in Brady bonds, which was created by intervention by the G-7 countries, is a case in point. More generally, Shiller (2004) has shown that markets in any number of innovative financial assets with desirable risk-sharing properties developed only with the help of official intervention; U.S. examples include mortgage-backed securities (whose advent required the creation of Fannie Mae and Freddie Mac) and TIPS (inflation-indexed treasury securities, whose creation had wait on the intervention of the federal government). Another widely-cited example is the addition of collective action clauses to the contracts governing bonds issued in the United States, which was helped by a concerted push by the international policy community.

These observations provide the motivation for proposals that some fraction of the reserves of Latin American countries be pooled through an entity like FLAR and used to relax the constraints on the development of markets in financial instruments with desirable risk-sharing characteristics. Inspiration can be drawn, as noted above, from the Asian Bond Fund in which EMEAP countries allocated a portion of their reserves to a fund authorized to purchases government and quasi-government securities - in the case of ABF-I foreign-currency-denominated securities, in the case of ABF-II local-currencydenominated securities - and to create regional bond market indices. These purchases are designed to widen the installed base and achieve critical mass of transactions, while

\footnotetext{
${ }^{31}$ This will especially be the case when the decision must be taken by potentially short-lived governments with understandably high discount rates, which care more about the up-front costs than the deferred benefits.
} 
creation of the indices is designed to stimulate demand by institutional investors seeking to track them.

In the Latin American context, observers have recommended a variety of steps to foster markets in financial instruments with cyclical properties superior to foreigncurrency-denominated bonds. These include the aforementioned CPI-indexed domesticcurrency bonds, payments on which do not rise when the terms of trade deteriorate (Eichengreen and Hausmann 2005b). They include GDP-indexed bonds, payments on which rise only when domestic incomes rise (Borensztein and Mauro 2004). ${ }^{32}$ They include bonds indexed to the prices of one or more commodities, Chilean bonds indexed to the price of copper being a favorite example (Caballero 2001). ${ }^{33}$

Investors should find these instruments attractive, assuming the existence of sufficiently liquid markets. CPI-indexed bonds offer protection against inflation; in this respect they have the same attractive characteristics as foreign-currency-denominated bonds. ${ }^{34}$ Since national growth rates are imperfectly correlated, investors should be able to diversify away the idiosyncratic risk associated with GDP-indexed bonds. ${ }^{35}$ For investors who do not wish to diversify, GDP-indexed bonds would offer a way of taking a position on a country's growth rate (acquiring an equity-like exposure). Such bonds should exhibit lower default rates than plain-vanilla issues (since payments rise only

\footnotetext{
${ }^{32}$ This idea was also advanced by the U.S. President's Council of Economic Advisors (2004) endorsed at the 2004 Summit of the Americas.

${ }^{33}$ These bonds could be indexed to the price of copper or include a put option that kicks when that price falls to a specified threshold level. There are also arguments for even more innovative instruments such as long-term GDP growth swaps, which might be arranged as parallel (back-to-back) loan agreements indexed to the participating countries' GDPs (Shiller 2004).

${ }^{34}$ And there is no particular reason to expect a secular deterioration in the terms of trade of the issuer. A cyclical deterioration owing to, inter alia, a sudden stop is a different story, of course, but to the extent that such a terms of trade movement is presumably temporary, investors should not be deterred. And to the extent that such instruments have better risk-sharing characteristics (the share of real income that must go to make payments does not rise when the terms of trade deteriorate and hence real incomes fall), default rates are likely to be lower, rendering the instrument more attractive still.

${ }^{35}$ This is an admittedly controversial point, to which I return below.
} 
when national incomes rise), rendering them even more attractive to investors. The idiosyncratic risk associated with commodity bonds may be more pronounced, but such bonds should be attractive to, inter alia, corporates that are users of the commodities in question (since interest income will then rise with the cost of the commodity). ${ }^{36}$

To be sure, CPI and GDP statistics are subject to revision and, potentially, manipulation. This last problem can be solved, or at least ameliorated, by delegating to third parties the responsibility of estimating GDP. Thus, when Bulgaria issued GDP warrants in 1994, it specified that the World Bank should compile the relevant GDP statistics. ${ }^{37}$ The manipulability of GDP statistics did not prevent Argentina from including GDP warrants in the menu of options in its recent debt restructuring. ${ }^{38}$ To the extent that a country's growth rate (unlike commodity prices, which tend to be determined on world markets) is a function of its policies, there is a moral hazard, but it is hard to imagine a country that would want to grow more slowly simply in order to limit its debt service.

The most plausible explanation for lack of wider acceptance of such instruments is that there does not exist an adequate installed base, limiting liquidity. Someone has to go first in order to create a liquid market, and no one is willing to go first in the absence of adequate liquidity. The more other countries issue GDP-indexed bonds, the greater the demand for the GDP-index bonds of the next country from investors seeking to create a diversified potfolio of such instruments. Creating a market therefore requires solving a

\footnotetext{
${ }^{36}$ Thus, Mexico has been able to issue bonds indexed to oil prices, although it has had to pay a novelty/liquidity premium. A number of private Chilean firms have issued bonds indexed to the price of copper.

${ }^{37}$ Unfortunately, it did not specify whether the Bank should compile statistics on GDP at factor costs or market prices - or even specify whether the relevant clause referred to nominal or real GDP, a problem that would presumably be addressed in future issues.

${ }^{38}$ Costa Rica and Bosnia-Herzegovina also issued bonds including GDP warrants or indexation clauses as part of their Brady restructurings.
} 
coordination problem - getting everyone to move together. ${ }^{39}$ This is the conundrum that the Asian Bond Fund is designed to address in another regional context.

The simplest approach to this problem is that of U.S. Council of Economic Advisors (2004), which suggests that multilateral financial institutions like the World Bank and Interamerican Development Bank could consider initially purchasing a portion of the newly-issued bonds to guarantee a minimum size for the market. ${ }^{40}$ FLAR could similarly devote a portion of its portfolio to purchases of these financial instruments, thereby following in the footsteps of the ABF. ${ }^{41}$ Caballero (2003) suggests that this initiative might be supplemented by creating a CDO (Collateralized Debt Obligation) structure. The CDO would purchase a diversified portfolio of emerging market contingent bonds and use these to back its own issues. The senior tranches of those issues would absorb the contingency risk but not the default risk associated with the underlying securities and thus be attractive to a wide range of nonspecialist investors lacking detailed information on country risk. The junior (mezzanine) tranches would appeal to specialist investors prepared to assume country risk or could be held by FLAR itself.

Would doing so be consistent with FLAR's fiduciary responsibilities? Currently, FLAR's Board of Directors requires the institution to invest exclusively in investmentgrade securities. According to FLAR (2004), the institution's self-managed portfolio is fully hedged against the U.S. dollar, again by mandate from the Board. In addition, all

\footnotetext{
${ }^{39}$ In addition, there is the tendency for investment professionals to under-invest in designing innovative financial instruments insofar as new securities are easily emulated, rendering returns difficult to capture (Allen and Gale 1994, Athanasoulis, Shiller and van Wincoop 1999).

${ }^{40}$ U.S. Council of Economic Advisors (2004), p.8.

${ }^{41}$ Since FLAR tends to be a buy-and-hold investor it is not clear whether this would contribute significantly to market liquidity. This is the same knock that has been made against the ABF. Moreover, if the constraint on market growth is the absence of a risk-free benchmark security, simply adding to the demand for risky securities would not eliminate the problem.
} 
positions taken by external fund managers contracted by FLAR to manage portions of its portfolio are denominated in U.S. dollars. Thus, for FLAR to purchase local-currencydenominated debt instruments, the Board would have to agree to a change in mandate and practice. Preceding arguments about how international investors should find these instruments attractive given the development of adequate market liquidity suggests that a limited move in this direction would be consistent with directors' fiduciary responsibilities.

Even if it is concluded that such purchases would be a responsible use of FLAR's resources, they would produce the desired result only if undertaken in conjunction with other initiatives. FLAR, the World Bank, or another outside entity would have to be designated as the source of the economic statistics to which interest payments are indexed. Bond market indices would have to be created to stimulate the demand by investment funds and other institutional investors.

Eichengreen and Hausmann (2005b) recommend that the World Bank and Interamerican Development Bank borrow as well as lend by issuing inflation-indexed local-currency bonds. Because the IFIs are AAA rated, claims on the World Bank and IDB would be more attractive than similarly denominated claims on residents. Their issues would provide a convenient asset for pension funds required by their mandates to hold investment grade assets and previously forced to purchase foreign securities in order to obtain them. They would provide a convenient benchmark off of which to price riskier placements. By bundling issues denominated in different currencies into a composite, the IFIs can make it attractive for foreign investors concerned with transaction and management costs to add these securities to their portfolios. By creating an EM index, they can create a demand on the part of institutional investors to track them. These 
transactions would be free of currency risk for the IFIs insofar as they matched their borrowing in Latin American currencies with loans in those same currencies. The World Bank has engaged in some experimentation with this approach, for example issuing a Colombian peso CPI-indexed bond in 2004. A few months later the IDB issued a Eurobond in Brazilian reais with similar motivation.

This approach could be emulated by FLAR. In 2003 the organization issued medium-term notes that traded at a price equivalent to 15 basis points over LIBOR. ${ }^{42}$ FLAR (2004) describes an effort underway to issue additional medium-term notes via the private placement market, as noted above. Those notes could be denominated in local currency and indexed for inflation as a way of helping to build a customer base for local currency bonds. In order to have the effect of helping to introduce a benchmark (riskfree) asset, that borrowing could not however exceed levels consistent with the maintenance of FLAR's investment grade rating.

A potential objection to such proposals is that the same clustering of shocks that reduces the attractiveness of regional coinsurance may reduce the attractiveness of these contingent claims. If growth rates in different Latin American and Caribbean countries all move together, owing to common exposure to global shocks, then returns on their GDP-indexed financial obligations will similarly tend move together, limiting the diversification benefits to investors and making it difficult for these countries as a group to all place significant quantities of these claims with the markets.

This objection is likely to apply more powerfully to some financial claims than to others. In any case, the question is not whether the returns on such obligations tend to

\footnotetext{
${ }^{42}$ According to the latest information I have these notes account for about a third of FLAR's total liabilities.
} 
move together but whether they tend to move together more or less than traditional instruments denominated in foreign currency, which LAC countries already succeed in placing with international investors. Eichengreen and Hausmann (2005b) use historical data to compare volatility vis-à-vis the dollar of two inflation-adjusted baskets of emerging market currencies, showing that these are less volatile than both the yen and the deutschemark. This can be thought of a mimicking the returns on a basket of inflationindexed emerging-market securities. The relatively low volatility of the basket reflects the extent to which movements in real exchange rates (nominal exchange rates adjusted for inflation) are less than perfectly correlated across countries. ${ }^{43}$ To the extent that interruptions to debt service will be less when inflation-indexed domestic-currency instruments are substituted for foreign-currency debt, since debt service will then be better insulated from terms-of-trade shocks, such a basket would be even more attractive to international investors relative to the alternative of dollar- (and euro- and yen-) denominated bonds.

In sum, FLAR could contribute to financial stability in its member countries by using some portion of its reserve pool to invest in their issuance of state-contingent debt securities with desirable risk-sharing properties. But such an initiative will be effective only if it is complemented by efforts to develop a regional index of such securities, by the creation of a CDO structure, and by other steps to further develop the market. ${ }^{44}$

\footnotetext{
${ }^{43}$ Eichengreen and Hausmann note that while the coincidence of sudden stops may tend to increase the covariance and volatility of returns, the tendency for terms-of-trade shocks affecting different emerging markets to offset (a shock to oil prices will be a positive shock to oil exporters but a negative shock to oil importers) works to reduce covariance and volatility. Thus, the attractiveness to investors of a basket of domestic-currency-denominated inflation-indexed emerging market bonds reflects the fact that returns incorporate the effects of both types of shocks and not just the effects of sudden stops.

${ }^{44}$ In addition, Levy Yeyati (2004b) argues that the official development banks should lend in local currencies, thereby enhancing the liquidity of markets in domestic-currency-denominated debt and creating a risk-free domestic-currency benchmark off of which domestic credits can be more easily priced. But it is
} 


\section{Relationship to the IMF, World Bank and IDB}

There are a number of arguments for why these initiatives should be coordinated with the activities of the IMF, World Bank, and IDB. In the case of emergency lending, there is the fact that more lending by FLAR will not increase the resources available to a crisis country if it just reduces IMF lending dollar for dollar. Additionality would remain if the increase in FLAR lending exceeded the IMF's overall willingness to lend, but cannot be assumed. Thus, for reserve pooling designed to enhance the provision of country insurance to succeed in providing improved protection against sudden stops, there would have to be a consensus among the directors of FLAR and the Executive Directors of the IMF on the desirability of a greater volume of emergency financing. In addition, there are compelling arguments for why responsibility for surveillance and conditionality should be delegated to an entity outside the region, such as the IMF, that is better capable of following time-consistent policies. In addition, there is the obvious fact that two last-resort lenders, the IMF and FLAR, could not independently attach conditions to their lending, since the policy implications could be contradictory and incompatible. It is revealing that Asian countries, in negotiating the Chiang Mai Initiative of swap lines and credits, agreed that initial disbursement could occur only in conjunction with an IMF program and should be subject to IMF conditionality. Similar arguments can be made in favor of coordinating the investment of FLAR funds to promote the liquidity of markets in innovative local-currency financial instruments with the financial-development initiatives of the IFIs. The risks associated with taking

hard to see how this idea could be carried over to FLAR, insofar as the latter specializes in emergency lending, which is necessarily denominated in foreign currency. 
positions in these markets can be spread between the World Bank, the IDB and FLAR if they all borrow and lend in these markets and using these instruments. More

fundamentally, financial market development requires not just willingness on the part of a few large players to take positions in the relevant instruments but also the development of efficient market infrastructure to encourage continuing transactions. Here the IFIs are already involved, the World Bank through the provision of technical assistance, the IMF and World Bank through their joint Financial Sector Assessment Programs, and the IDB through its network of researchers engaged in the study of local bond markets. Ideally, FLAR's portfolio allocation decisions should be tailored to lever up these same infrastructure-building efforts and thus should be closely coordinated with them.

The conclusion that a regional coinsurance or financial-development initiative funded by pooling international reserves should be coordinated with the emergencylending and financial-development efforts of the global institutions will disappoint those who might have hoped that by mobilizing their reserves more efficiently Latin American countries could free themselves on dependence on the IFIs. Such hopes were similarly disappointed in Asia. In practice, there is no alternative to continued close coordination with the IFIs.

\section{Conclusion}

This paper has explored two routes through which the pooling of reserves through FLAR could enhance stability and welfare in Latin America. First, the reserve pool could be used for emergency lending in response to sudden stops. Insofar as the incidence of sudden stops differs across countries, pooling would allow the same reserves to support a 
larger volume of emergency lending. ${ }^{45}$ This image has considerable appeal. Practically speaking, however, such a scheme would have to surmount significant obstacles. Sudden stops may be imperfectly correlated across countries, but they also have a pronounced regional element. They bunch temporally and regionally, and the literature on contagion gives good reasons to think that this will remain the case. The greater the bunching, the less the advantages of pooling. Emergency lending also creates a moral hazard that weakens crisis prevention and recovery efforts - especially when the insurer values the welfare of the insured, creating time consistency problems for ex ante contracts. Surveillance and conditionality address this problem, but they work imperfectly. Compared to agencies subject to independent regulation, self-regulating entities like FLAR also show a greater tendency toward forbearance, which is likely to further aggravate moral hazard. Knowing that this reduces the probability of repayment, governments may reasonably be reluctant to commit a significantly increased share of their hard-earned international reserves to the regional pool. Finally, it is not realistic to assume that FLAR can unambiguously determine whether a country is experiencing a crisis of insolvency or illiquidity. Knowing that there is a nonnegligible risk that it might deploy their resources on the basis of erroneous assumptions, governments and central banks might be even more reluctant to contribute to the pool.

A more promising route would be to use a portion of the reserve pool, along with borrowed funds, to purchase contingent debt securities issued by Latin American governments and corporations: domestic-currency inflation-indexed bonds, GDP-indexed bonds, commodity-price-indexed bonds. This would help to solve the coordination/first-

\footnotetext{
${ }^{45}$ Or for fewer real resources to be devoted to underwriting the same amount of emergency lending.
} 
mover problem that limits the liquidity of markets in these instruments and hinders their acceptance by private investors.

Neither initiative should be thought of in stand-alone terms. An expanded emergency lending facility should be complemented by stronger regional surveillance and national policy reform. Similarly, there is no reason why, in addition to creating an expanded reserve pool for use in emergency lending, governments could not also push ahead with issuing contingent debt securities that reduce their vulnerability to disturbances. Finally, there is a convincing case for coordinating such initiatives with the global financial institutions. If emergency lending is not coordinated, there is a danger that an additional dollar of FLAR money will simply be offset by one less dollar of IMF money. Analogously, the World Bank and IDB can complement FLAR's efforts to develop the market in local-currency-denominated contingent securities because they can issue as well as purchase claims denominated in those currencies and because their credit rating is AAA. Working together would enable FLAR and the IFI's to maximize their impact. Working separately would be an opportunity missed. 


\section{References}

Adalet, Muge and Barry Eichengreen (2005), "Current Account Reversals: Always a Problem?" paper presented to the NBER Conference on G-7 Current Account Imbalances, Newport, Rhode Island (June).

Aizenman, Joshua and Jaewoo Lee (2005), "International Reserves: Precautionary Versus Mercantilist Views, Theory and Evidence," NBER Working Paper no. 11366 (May).

Allen, Franklin and Douglas Gale (1994), Financial Innovation and Risk Sharing, Cambridge, Mass.: MIT Press.

Athanasoulis, Stefano, Robert Shiller and Eric van Wincoop (1999), "Macro Markets and Financial Security,” FRBNY Economic Policy Review (April), pp.21-39.

Berganza, Juan Carlos and Alicia Garcia Herrero (2004), "What Makes Balance Sheet Effects Detrimental for the Country Risk Premium?" unpublished manuscript, Bank of Spain.

Borensztein, Eduardo and Paolo Mauro (2004), "The Case for GDP-Indexed Bonds," Economic Policy (April), pp.165-216.

Broda, Christian. and Eduardo Levy-Yeyati (2003), "Dollarization and the Lender of Last Resort," in Eduardo Levy-Yeyati and Federico Sturzenegger (eds), Dollarization: Debates and Policy Alternatives, Cambridge, Mass.: MIT Press.

Byun, Jennie and William Oswald (2005), "Emerging Markets as an Asset Class," J.P. Morgan Emerging Markets Research (October).

Caballero, Ricardo J. (2001), "Coping with Chile's External Vulnerability: A Financial Problem," unpublished manuscript, MIT (July).

Caballero, Ricardo J. (2003), “On the International Financial Architecture: Insuring Emerging Markets,” NBER Working Paper no.9570 (March).

Caballero, Ricardo J. and Stavros Panageas (2005), "A Quantitative Model of Sudden Stops and External Liquidity Management," NBER Working Paper no. 11293 (April).

Calvo, Guillermo A. (1998), "Capital Flows and Capital-Market Crises: The Simple Economics of Sudden Stops," Journal of Applied Economics 1, pp.35-54.

Calvo, Guillermo A. (2002), "Globalization Hazard and Delayed Reform in Emerging Markets,” Economia (Spring), pp.1-29.

Calvo, Guillermo A. (2005), "Crises in Emerging Market Economies: A Global Perspective,” NBER Working Paper no. 11305 (April). 
Calvo, Guillermo A., Alejandro Izquierdo, and Luis F. Mejia (2004), "On the Empirics of Sudden Stops: The Relevance of Balance-Sheet Effects," NBER Working Paper no. 10520 (May).

Calvo, Guillermo A. and Carmen M. Reinhart (1999), "Capital Flow Reversals, the Exchange Rate Debate, and Dollarization," Finance and Development 36 (3), pp.13-15.

Cespedes, Luis, Roberto Chang and Andres Velasco (2000), "Balance Sheet Effects and Exchange Rate Policy,” NBER Working Paper no. 7840 (August).

Chami, Ralph, Sunil Sharma and Ilhyock Shim (2004), "A Model of the IMF as a Coinsurance Arrangement," IMF Working Paper no. 04/219 (November).

Cohen, Daniel and Richard Portes (2004), “Towards a Lender of First Resort,” CEPR Discussion Paper no. 4615 (September).

Cordella, Tito and Eduardo Levy Yeyati (2004), "Country Insurance," IMF Working Paper no. 04/148 (August)Staff Papers 52 (special issue), pp.85-106..

Cordella, Tito and Eduardo Levy Yeyati (2005), “A (New) Country Insurance Facility," IMF Working Paper no. 05/23 (January).

DeMazo, Peter, Michael Fishman and Kathleen Hagerty (2001), “The Enforcement Policy of a Self-Regulatory Organization," unpublished manuscript, Stanford University (April).

Dervis, Kemal and Ceren Ozer (2005), A Better Globalization: Legitimacy, Government and Reform, Washington, D.C.: Center for Global Development.

Dodsworth, John R. (1992), "Reserve Pooling: An Application of the Theory of Clubs," Economia Internazionale 44, pp.209-222.

Domac, I. and Soledad Maria Martinez Peria (2000), "Banking Crises and Exchange Rate Regimes: Is There a Link?" unpublished manuscript, the World Bank (November).

Edwards, Sebastian (2005), "Capital Controls, Sudden Stops and Current Account Reversals," NBER Working Paper no. 11170 (March).

Eichengreen, Barry (2002), Financial Crises and What to Do About Them, Oxford: Oxford University Press.

Eichengreen, Barry, Poonam Gupta and Ashoka Mody (2005), "Sudden Stops and IMF Programs," paper prepared for the Interamerican Seminar on Macroeconomics, Rio, 2-3 December. 
Eichengreen, Barry and Ricardo Hausmann, eds. (2005a), Other People's Money: Debt Denomination and Financial Instability in Emerging Market Economies, Chicago: University of Chicago Press.

Eichengreen, Barry and Ricardo Hausmann (2005b), “The Road to Redemption,” in Barry Eichengreen and Ricardo Hausmann eds., Other People's Money: Debt Denomination and Financial Instability in Emerging Market Economies, Chicago: University of Chicago Press, pp.266-288.

FLAR (2004), “Descriptive Document,” Bogata: FLAR.

Gagnon, Joseph (2005), "Currency Crashes and Bond Yields in Industrial Countries," International Finance Discussion Paper no.837, Washington, D.C.: Board of Governors of the Federal Reserve System (August).

Glick, Reuven and Andrew Rose (1998), "Contagion and Trade: Why Are Currency Crises Regional?” NBER Working Paper no. 6806 (November).

Heller, H. Robert (1970), "Wealth and International Reserves," Review of Economics and Statistics 52, pp.212-214.

International Monetary Fund (2003), “Are Foreign Exchange Reserves in Asia Too High?” World Economic Outlook (September), pp.78-92.

Lane, Timothy and Steve Philips (2000), "Does IMF Financing Result in Moral Hazard?" IMF Working Paper no. 00/168.

Lee, Jaewoo (2004), "Insurance Value of International Reserves: An Option Pricing Approach,” IMF Working Paper no. 04/175 (September).

Levy Yeyati, Eduardo (2004a), "Financial Dollarization: Evaluating the Consequences," unpublished manuscript, Universidad Torcuato Di Tella (August).

Levy Yeyati, Eduardo (2004b), "Dollars, Debt and the IFIs: Dedollarizing Multilateral Lending," Working Paper 11/2004, Buenos Aires: Universidad Torcuato Di Tella (September)

Shiller, Robert (2004), The New Financial Order: Risk in the Twenty First Century, Princeton: Princeton University Press.

United States President, Council of Economic Advisors (2004), "White Paper: GrowthIndexed Bonds: A Primer," unpublished manuscript, Council of Economic Advisors (November).

Williams, Oral, Tracey Polius and Selvon Hazel (2001), "Reserve Pooling in the Eastern Caribbean Currency Union and the CFA Franc Zone: A Comparative Analysis," IMF Working Paper WP/01/104 (August). 
Williamson, John (2005), "Curbing the Boom-Bust Cycle: Stabilizing Capital Flows to Emerging Markets," Policy Analysis in International Economics no. 75, Washington, D.C.: Institute for International Economics (July). 
Table 1. Reserve Variability, 1978-2005

\begin{tabular}{||l|c|c|c||}
\hline Country & $\begin{array}{c}\text { Mean } \\
\text { Reserves }\end{array}$ & $\begin{array}{c}\text { Standard } \\
\text { Deviation }\end{array}$ & $\begin{array}{c}\text { Coefficient } \\
\text { of Variation } \\
\text { Reserves }\end{array}$ \\
\hline Bolivia & 462.78 & 387.31 & 0.84 \\
Colombia & 6621.39 & 3684.68 & 0.56 \\
Costa Rica & 889.03 & 582.96 & 0.66 \\
Ecuador & 1005.30 & 503.08 & 0.50 \\
Peru & 5049.93 & 4453.21 & 0.86 \\
Venezuela & 9739.91 & 4436.65 & 0.46 \\
\hline
\end{tabular}


Table 2. Coverage Ratios, 1978-2005

\begin{tabular}{||l|c|c|c|c|c|c|c|c|c|c|c||}
\hline \hline Country & $\boldsymbol{P}=\mathbf{0 . 0}$ & $\boldsymbol{P}=\mathbf{0 . 1}$ & $\boldsymbol{P}=\mathbf{0 . 2}$ & $\boldsymbol{P}=\mathbf{0 . 3}$ & $\boldsymbol{P}=\mathbf{0 . 4}$ & $\boldsymbol{P}=\mathbf{0 . 5}$ & $\boldsymbol{P}=\mathbf{0 . 6}$ & $\boldsymbol{P}=\mathbf{0 . 7}$ & $\boldsymbol{P}=\mathbf{0 . 8}$ & $\boldsymbol{P}=\mathbf{0 . 9}$ & $\boldsymbol{P}=\mathbf{1 . 0}$ \\
\hline Bolivia & 1.19 & 1.72 & 1.78 & 1.80 & 1.81 & 1.82 & 1.83 & 1.83 & 1.83 & 1.83 & 1.84 \\
Columbia & 1.80 & 1.83 & 1.84 & 1.84 & 1.84 & 1.84 & 1.84 & 1.84 & 1.84 & 1.84 & 1.84 \\
Costa Rica & 1.53 & 1.78 & 1.82 & 1.82 & 1.82 & 1.83 & 1.83 & 1.83 & 1.83 & 1.83 & 1.84 \\
Ecuador & 2.00 & 2.00 & 1.89 & 1.89 & 1.88 & 1.86 & 1.85 & 1.84 & 1.84 & 1.84 & 1.84 \\
Peru & 1.16 & 1.34 & 1.55 & 1.55 & 1.62 & 1.68 & 1.72 & 1.76 & 1.79 & 1.81 & 1.84 \\
Venezuela & 2.20 & 2.14 & 2.04 & 2.04 & 2.00 & 1.96 & 1.93 & 1.90 & 1.88 & 1.85 & 1.84 \\
\hline
\end{tabular}


Table 3. Hypothetical Reserves, 1978-2005

\begin{tabular}{|c|c|c|c|c|c|c|c|c|c|c|c|}
\hline Country & $P=0.0$ & $P=0.1$ & $P=0.2$ & $P=0.3$ & $P=0.4$ & $P=0.5$ & $P=0.6$ & $P=0.7$ & $P=0.8$ & $P=0.9$ & $P=1.0$ \\
\hline Bolivia & 462.8 & 667.7 & 689.9 & 698.2 & 702.6 & 705.3 & 707.1 & 708.4 & 709.4 & 710.2 & 710.8 \\
\hline Columbia & 6621.4 & 6728.6 & 6771.2 & 6787.0 & 6790.9 & 6789.1 & 6784.8 & 6779.3 & 6773.5 & 6767.7 & 6762.0 \\
\hline Costa Rica & 889.0 & 1035.8 & 1053.8 & 1060.4 & 1063.7 & 1065.8 & 1067.1 & 1068.1 & 1068.8 & 1069.4 & 1069.8 \\
\hline Ecuador & 1005.3 & 1007.6 & 970.7 & 953.3 & 943.4 & 937.0 & 932.6 & 929.3 & 926.8 & 924.8 & 923.2 \\
\hline Peru & 5049.9 & 5818.9 & 6359.1 & 6756.6 & 7060.0 & 7298.7 & 7490.9 & 7648.9 & 7780.9 & 7892.8 & 7988.9 \\
\hline Venezuela & 9739.9 & 9515.7 & 9281.4 & 9065.1 & 8873.7 & 8706.9 & 8562.0 & 8435.7 & 8325.2 & 8228.0 & 8142.0 \\
\hline
\end{tabular}


Table 4. Correlation of International Reserves, 1978-2005

\begin{tabular}{|l|c|c|c|c|c|c||}
\hline & Bolivia & Colombia & Costa Rica & Ecuador & Peru & Venezuela \\
\hline Bolivia & 1.0000 & & & & & \\
\hline Colombia & 0.8313 & 1.0000 & & & & \\
\hline Costa Rica & 0.8193 & 0.9064 & 1.0000 & & & \\
\hline Ecuador & 0.7146 & 0.6320 & 0.5111 & 1.0000 & & \\
\hline Peru & 0.9537 & 0.9248 & 0.8775 & 0.7215 & 1.0000 & \\
\hline Venezuela & 0.7708 & 0.7733 & 0.7979 & 0.5210 & 0.7856 & 1.0000 \\
\hline
\end{tabular}


Table 5. Correlation of International Reserves, 1978-2005

\begin{tabular}{||l|c|c|c|c|c|c||}
\hline & Bolivia & Colombia & Costa Rica & Ecuador & Peru & Venezuela \\
\hline Bolivia & 1.0000 & & & & & \\
\hline Colombia & 0.3338 & 1.0000 & & & & \\
\hline Costa Rica & 0.1165 & 0.3375 & 1.0000 & & & \\
\hline Ecuador & 0.5585 & 0.3819 & -0.0660 & 1.0000 & & \\
\hline Peru & 0.8413 & 0.6167 & 0.1588 & 0.6166 & 1.0000 & \\
\hline Venezuela & 0.4728 & 0.4577 & 0.6301 & 0.2297 & 0.4970 & 1.0000 \\
\hline
\end{tabular}


Table 6. Reserve Variability, 1978-2005 (detrended reserves)

\begin{tabular}{|l|c|c|c||}
\hline \hline & $\begin{array}{c}\text { Mean } \\
\text { Reserves }\end{array}$ & $\begin{array}{c}\text { Standard } \\
\text { Deviation }\end{array}$ & $\begin{array}{c}\text { Coefficient } \\
\text { of Variation } \\
\text { Reserves }\end{array}$ \\
\hline Bolivia & 462.78 & 213.76 & 0.46 \\
\hline Colombia & 6621.39 & 1598.25 & 0.24 \\
\hline Costa Rica & 889.03 & 160.82 & 0.18 \\
\hline Ecuador & 1005.30 & 420.95 & 0.42 \\
\hline Peru & 5049.93 & 1964.52 & 0.39 \\
\hline Venezuela & 9739.91 & 3163.15 & 0.32 \\
\hline
\end{tabular}


Table 7. Coverage Ratios, 1978-2005 (detrended reserves)

\begin{tabular}{|l|l|l|l|l|l|l|l|l|l|l|l||}
\hline \hline Country & $\mathbf{0 . 0}$ & $\mathbf{0 . 1}$ & $\mathbf{0 . 2}$ & $\mathbf{0 . 3}$ & $\mathbf{0 . 4}$ & $\mathbf{0 . 5}$ & $\mathbf{0 . 6}$ & $\mathbf{0 . 7}$ & $\mathbf{0 . 8}$ & $\mathbf{0 . 9}$ & $\mathbf{1 . 0}$ \\
\hline Bolivia & 2.16 & 3.74 & 3.87 & 3.91 & 3.93 & 3.94 & 3.94 & 3.95 & 3.95 & 3.95 & 3.96 \\
\hline Colombia & 4.14 & 4.31 & 4.32 & 4.28 & 4.23 & 4.17 & 4.12 & 4.07 & 4.03 & 3.99 & 3.96 \\
\hline Costa Rica & 5.53 & 4.64 & 4.30 & 4.17 & 4.09 & 4.05 & 4.02 & 4.00 & 3.98 & 3.97 & 3.96 \\
\hline Ecuador & 2.39 & 3.82 & 3.96 & 3.98 & 3.98 & 3.97 & 3.97 & 3.97 & 3.96 & 3.96 & 3.96 \\
\hline Peru & 2.57 & 3.02 & 3.31 & 3.51 & 3.64 & 3.73 & 3.80 & 3.86 & 3.90 & 3.93 & 3.96 \\
\hline Venezuela & 3.08 & 3.30 & 3.47 & 3.60 & 3.70 & 3.77 & 3.83 & 3.88 & 3.91 & 3.94 & 3.96 \\
\hline
\end{tabular}


Figure 1: The stock of global reserves, 1970-2005

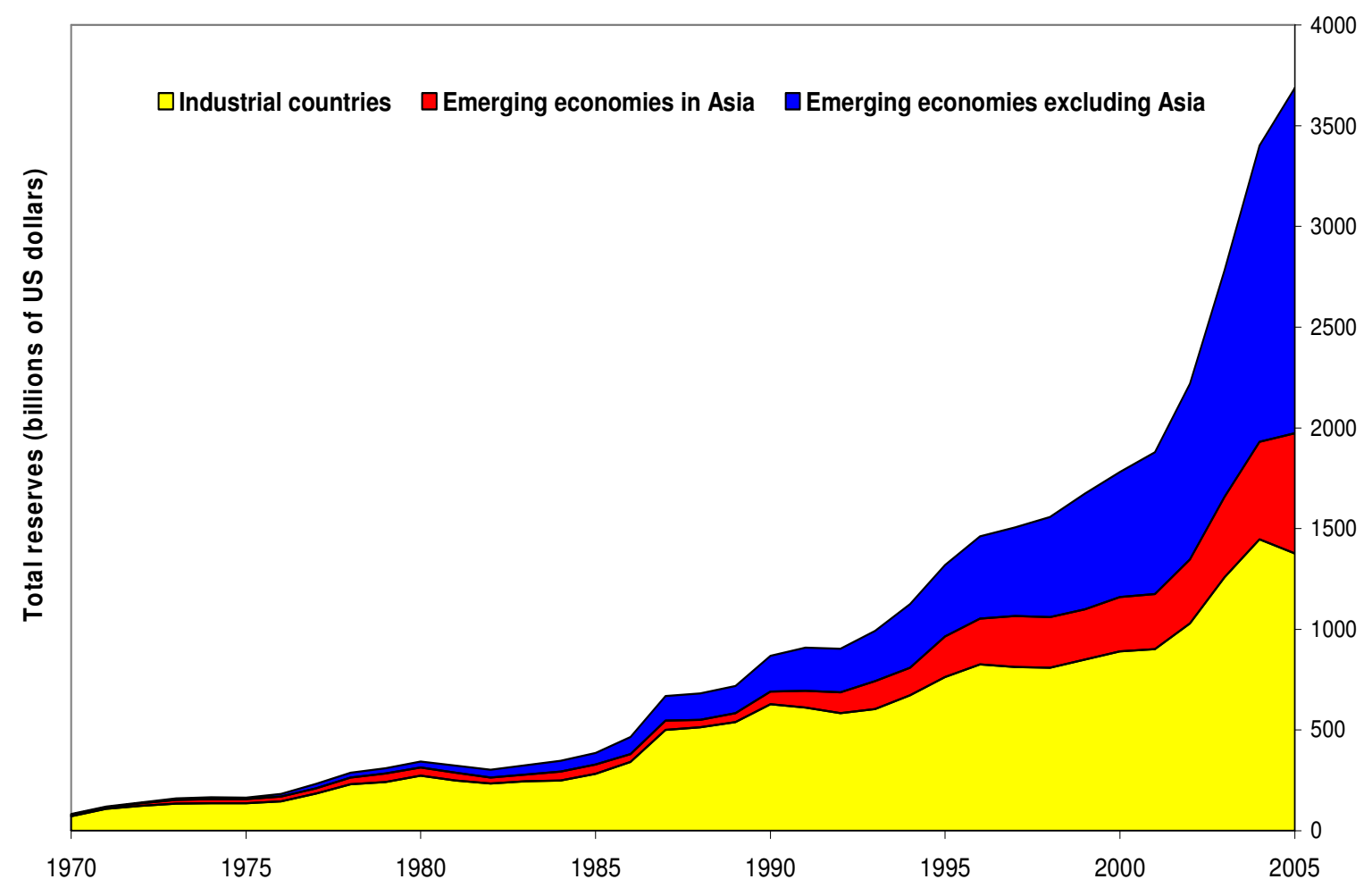

Source: IMF, International Financial Statistics. 
Figure 2
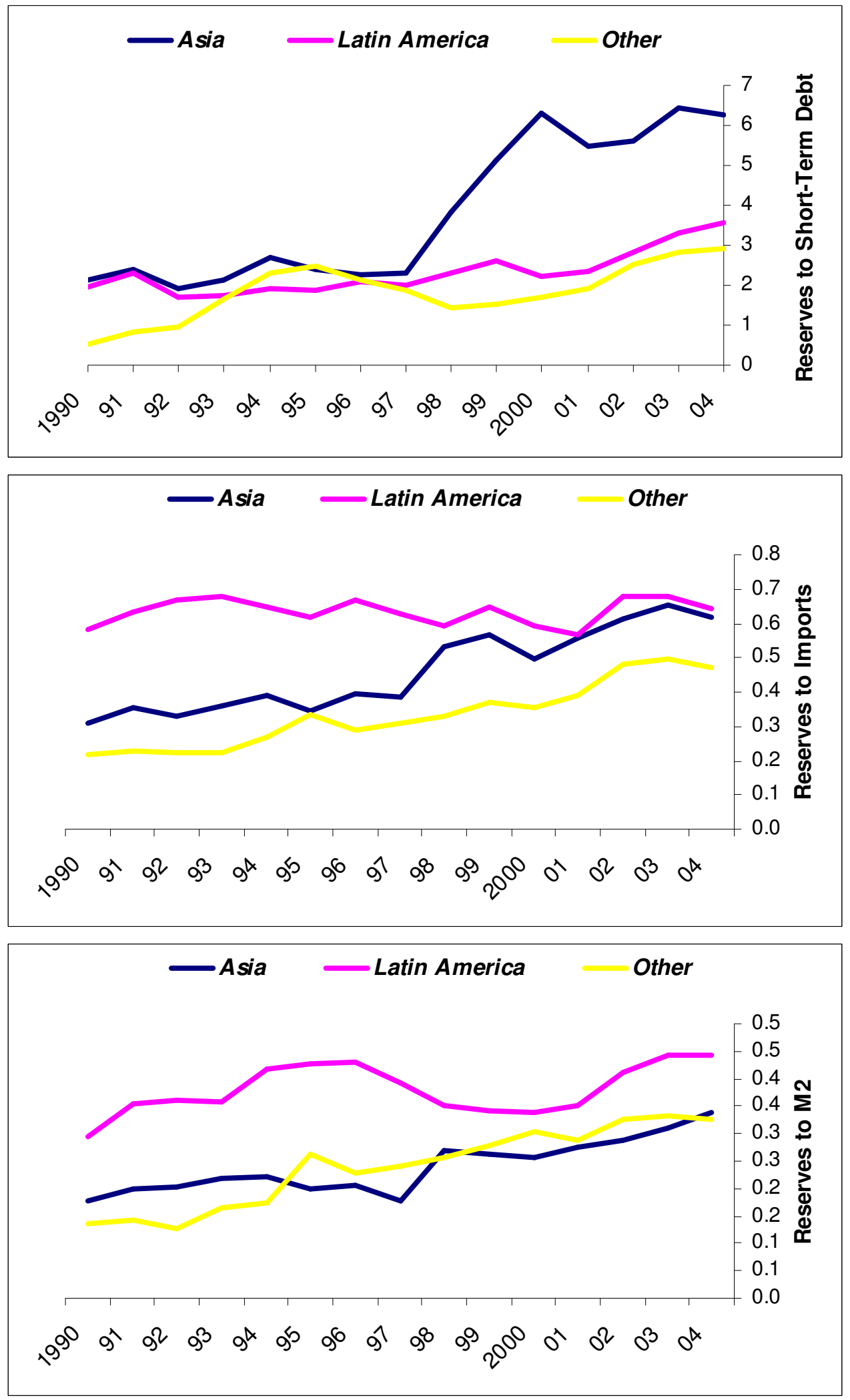

Source: International Financial Statistics and World Development Indicators. 
Figure 3

Probability of a Sudden Stop

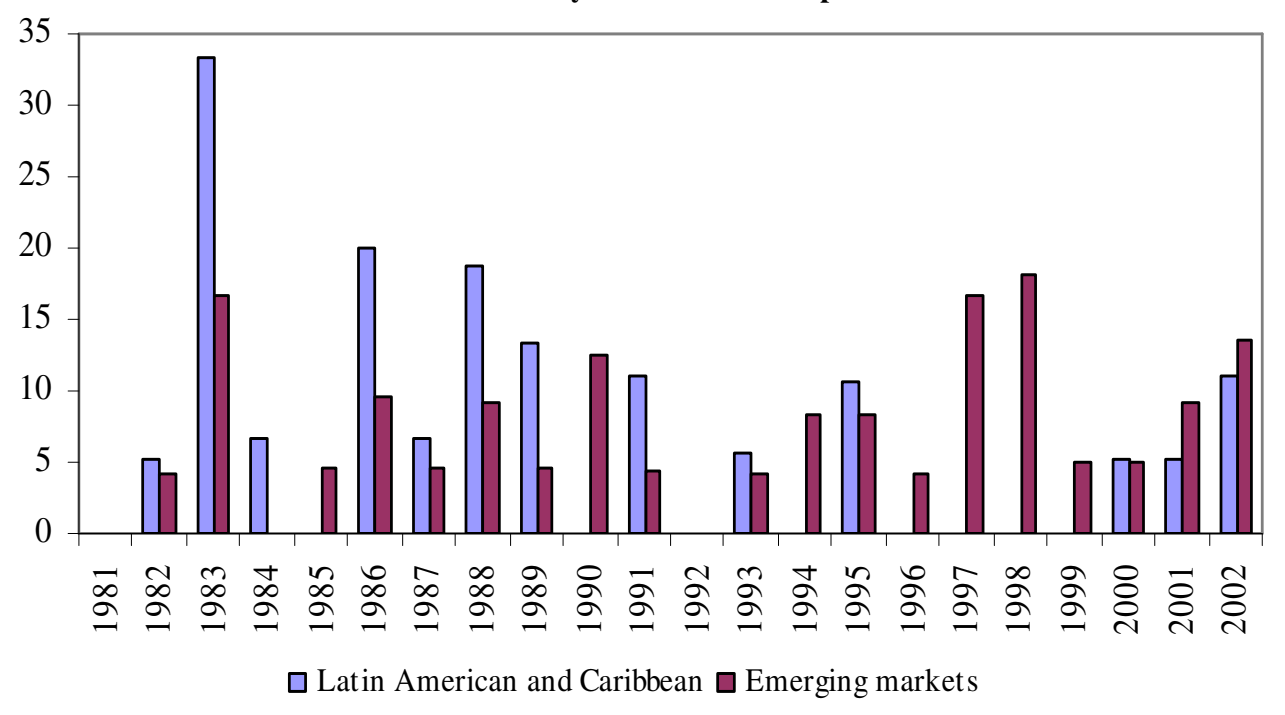

